\title{
NEGATION AND POLARITY \\ IN THE GREEK, GOTHIC, CLASSICAL ARMENIAN, AND OLD CHURCH SLAVIC GOSPELS: A PRELIMINARY STUDY
}

\author{
JARED S. KLEIN \\ University of Georgia
}

\section{[1] INTRODUCTION}

In the field of Indo-European syntax it is of course sound procedure to examine the earliest attested languages and texts, Hittite, Vedic Sanskrit, and Homeric Greek, in order to arrive at an assessment via reconstruction of the likely features of the syntax of the proto-language. But even in this seemingly straightforward procedure there lurks the difficulty that, whereas the texts of Homer and the Rigveda reflect archaic types of poetic production, the Hittite corpus consists overwhelmingly of prose. If we consider the syntax of prose and poetry to be in some degree incommensurate, then the circumstances of our comparison are not ideal. On the other hand, we find among a small group of middle attested Indo-European dialects exactly the opposite situation: in Germanic, Armenian, and Slavic the earliest (or sole) attested material consists of translations from the Greek New Testament. In these instances, then, we have the same text and hence the materials for a readymade comparative syntax that simply awaits research in order to be made available as a component to be fed into the comparative method together with the results from other Indo-European dialects for the purpose of syntactic reconstruction. Despite these favorable circumstances, however, the comparative syntax of the Gothic, Classical Armenian, and Old Church Slavic gospels (for it is precisely these texts that they all share) has attracted exceedingly little attention. In fact, the only person to have devoted significant attention to this area prior to the twenty-first century was the Swiss scholar Cuendet, who wrote monographs on the use of the imperative and word order in these texts (1924 and 1929, respectively). Recognizing the obvious advantages for comparative syntax presented by this material, I conceived in 1987 a project to analyze these texts for comparative syntactic purposes and have pursued it ever since with many interruptions. My contributions have so far involved only Gothic and Classical Armenian (Klein 1992a, 1992b, 1994, 1996, 1997; Klein \& Condon 1993). In addition, over the past twenty years a number of unpublished theses and dissertations have been produced under my direction at the 
University of Georgia (in one instance elsewhere with me as co-director) as part of this project, mostly involving Gothic but with frequent inclusion of the Old English gospels (cf. Condon 1990, Kim 1992 [Old English], Tunkle 2000, Govberg-Afros 2002 [Gothic and Old English], Martin 2004 [Old English], Bucsko 2008, Pennington 2010 [Greek, Latin, Gothic, Old English]). In one instance (Thomason 2006) the material of Greek, Gothic, Classical Armenian, and Old Church Slavic has been utilized. In recent years Dag Haug has conceptualized a computerized European version of this project at Oslo University (called Pragmatic Resources in Old Indo-European Languages [PROIEL]) in which the Latin Vulgate also plays a prominent role. ${ }^{1}$ It appears therefore that the comparative syntax of these languages is finally getting the attention it deserves.

\section{[2] THE CORPUS}

The first step which must be taken in the consummation of this project is the accumulation of a body of comparative data. Currently no quadrilateral discussion of this material exists in the scholarly literature, aside from the works of Cuendet and Thomason previously noted. The data for such a discussion must therefore be wrung from the texts themselves. Once this material has been gathered and categorized, real syntactic analysis can begin. Pursuant to this goal, I will present here a preliminary study of the comparative syntax of negation and the related issue of negative polarity items. Its modest goal is to expose the comparative facts descriptively and venture a few preliminary analyses across a range of construction types, focusing especially on the formal exponents of these, including modality. With regard to the associated issue of negative polarity, this is not the place to expatiate upon this topic, on which a substantial literature now exists (cf. inter alios Fauconnier 1975, Ladusaw 1980, Horn 1989, Zwarts 1995). In this paper we will understand negative polarity items to refer to certain pronominal or adverbial elements that occur in negative contexts, including items translatable in English as 'nobody, never, nothing,' etc. For an in-depth study of negative polarity in the Classical Armenian gospel text cf. Klein 1997.

The corpus on which this analysis is based encompasses the Gospels of Matthew 1:1-11:25 and Mark, chapters 1-9 or just under $20 \%$ of the Gospel text in its entirety. For the Greek text, I have used the 26th edition of Nestle \& Aland (1979), for Gothic the sixth edition of Streitberg's Gotische Bibel (1971), and for Old Church Slavic Jagič's edition of the 11th century Codex Marianus (1960) with occasional variant readings taken from his edition of the Codex Zographensis (late 10th/early 11th century) (1954). For Classical Armenian I have used Künzle's critical edition of the 10th century Ëjmiacin manuscript (1984). The Armenian and Old Church Slavic texts are complete for the parts I have studied for this paper, although Jagič was forced to

[1] See http://foni.uio.no:3000. 
use the 13th century Dečani tetraevangelium to provide the text of Matthew 1:1-5:24, which is lacking in both the Marianus and the Zographensis; but the Gothic text is lacking for Mt 1:1-5:15 with brief lacunae between 6:32-7:12 and again between 10:1-23. In Mark as well Gothic lacks 6:31-54. I have broken down the negation into eleven or so categories representing for the most part different clause types with special consideration given to various negative polarity markers.

\section{[3] EXPONENTS OF NEGATION AND POLARITY}

Before presenting the comparative data, we begin by enregistering the basic exponents of negation and polarity in the four languages we are investigating, followed by an overview of their systems of modality and expression of futurity. These are features which will characterize all the passages which we shall subsequently cite and discuss.

The basic exponents of negation in the four languages are as follows:

(1) ou(k); modal mế ; sequential oúte, oudé; mête, mēdé

ni; sequential nih

[GK]

oč'; modal mi

[GoTH]

ne; sequential ni

While Greek and Classical Armenian retain the Indo-European distinction of indicative and modal negation, Gothic and Old Church Slavic employ a single form in both indicative and modal clauses. ${ }^{2}$ In the case of sequential negation only Classical Armenian shows no univerbated form but simply employs ew 'and' plus the relevant negation.

We next list the basic negative polarity items found in our corpus. The most striking of these is the Armenian set, where a series in - $k$ ' is opposed to a positive polarity series in -mn (oč' ok' 'nobody' vs. mi omn 'a certain one, somebody'). The relationship between these two is exactly like that of English any vs. some (cf. Klein 1997). Only Slavic, as we shall see, shows a pure negation ne in certain non-overtlynegative classical negative polarity contexts:

(2) 'Nobody, nothing'

ou/mēdeís, ou/mēdén

ni...manna/hashun, ni...waiht

$[\mathrm{GK}]$

oč' ok', oč' inč' (contrast positive mi omn, imn)

[GoTH]

niktože, ničtože

[2] The modal negators of both Greek and Classical Armenian are direct avatars of PIE * mé (cf. also Skt. mä). Similarly, Gothic ni and OCS ne both continue the PIE nonmodal negator *né. According to the etymology of Warren Cowgill (1960), both Gk ou( $k$ ) and Classical Armenian oč' are also descended from a strengthened form of *né, *né $\mathrm{H}_{2}$ óyu $k^{w}$ id 'not ever', with ellipsis of the original negator. If so, then both languages, like Sanskrit, originally opposed an indicative negator *né to a modal negator * mé. 


\begin{tabular}{lcccc}
\hline & Greek $^{1}$ & Gothic & Cl. Armenian & OCS \\
\hline Indicative & + & + & + & + \\
Imperative & + & + & + & $+^{2}$ \\
Subjunctive & + & $+^{3}$ & + & - \\
Future & + & -4 & $-^{5}$ & $-^{6}$ \\
\hline
\end{tabular}

${ }^{1}$ The optative is moribund and is not represented in our subcorpus. $\quad{ }^{2}$ Etymologically optative.

${ }^{3}$ Etymologically optative.

${ }^{4}$ Present indicative serves as future. ${ }^{5}$ Subjunctive serves as future. $\quad{ }^{6}$ Perfective present serves as future; periphrastic future with imati 'have' + infinitive.

TABLE 1: Modal categories

Finally, we note that although New Testament Greek, Classical Armenian, and Gothic all possess a subjunctive beside an indicative and imperative, OCS lacks this third modal category. NT Greek of course still employs the optative in reduced measure compared to its classical counterpart; but no examples of this mood occur in the negative clauses in our subcorpus. Although the Gothic subjunctive is etymologically an optative, we shall refer to it in this paper as a subjunctive. Of the four languages only Greek possesses a grammatical category called "future tense". In Gothic the present indicative is capable of signaling future value, and the same is true of the perfective present in OCS. In Classical Armenian the subjunctive, in addition to signaling a range of values normally associated with this mood, signals the future as well. These facts are synopsized in Table 1.

\section{[3.1] Simple negative statement}

We turn now to the various contexts of negation in comparative perspective. The first of these is the simple negative statement showing nonmodal negation + indicative mood in all four languages (3a). In the case of a future statement (3b) Greek juxtaposes the indicative and modal negations ou and $m \bar{e}$ and uses the subjunctive mood. Gothic responds with a present in future value and Armenian with oč + subjunctive qua future. In OCS the periphrastic verb imati + infinitive here signals future value: 
(3) a. Mt 6:24 'You cannot serve God and mammon'3 ou dúnasthe theôî douleúein kaì mamōnāî ni magup guda skalkinon jah mammonin oč' karēk' AY carayel ew mamonai ne možete bogu rabotati. i mamoně

b. Mt 5:20 'You shall not enter into the kingdom of heaven' ou mè̀ eisélthēte eis tèn basileían tôn ouranôn ni pau qimip in piudangardjai himine oč' mtanic'ēk' yark'ayowt'iwn erknic' ne imate vŭniti vŭ cěsarǐstvo nebešnoje

Example (3b) follows a negative conditional clause ('if/unless your justice is greater than [that] of the scribes and Pharisees') and only Gothic is sensitive to the apodotic nature of the context, employing its apodotic particle pau 'then'.

Turning now to some typical negative polarity contexts, we find instances involving the meanings 'nobody, nothing, no longer, and never', together with combinations of these. Examples are seen in (4a)-(4g):

(4) a. Mk 2:22 'And nobody puts new wine into old bottles'

kaì oudeìs bállei oînon néon eis askoùs palaioús ni manna giutip wein juggata in balgins fairnjans

Ew oč' ok' arkanē gini nor i tiks hins

i nikŭtože ne vŭlivaatŭ vina nova vı̌ měxy vetŭxy

b. Mk 9:39 'For there is nobody who shall do a miracle in my name and straightway speak evil of me'

oudeìs gàr estin hòs poiếsei dúnamin epì tôî onómatí mou kaì dunếsetai takhù kakologêsaí me ni mannahun auk ist saei taujip maht in namin meinamma jah magi sprauto ubilwaurdjan mis

[Gотн] zi oč ok' ē or ā̄nē zawrowt'iwns yanown im . ew karic'ē hayhoyel zis

niktože bo estŭ iže sŭtvoritŭ silǫ o imeni moemĭ. i vŭzmožetŭ vŭskorě zŭlosloviti mę

c. Mt 9:16 'Nobody puts a piece of unfulled cloth upon an old garment' oudeìs dè epibállei epíblēma hrákous agnáphou epì himatíoi palaiôî[GK] appan ni hashun lagjip du plata fanan parihis ana snagan fairnjana

[3] In presenting the texts I have made some simplifications driven in part by computer-related considerations. First, I have left off the line over holy names in Classical Armenian (e.g. AY, IEI) and have written out in full abbreviated words in OCS (e.g. bogu, čssaristvo nebesinnoje). I have also reduced the multiplicity of comma and period-like punctuations in Künzle's Classical Armenian text to a single period with a space on both sides and have placed the raised dot in Greek on the line. 
oč' ok' arkanē kapert ant'ap' i veray hnac'eal jorjoy

[ARM] niktože bo ne pristavlěatŭ pristavleniě plata ne bělena rizě vetŭsě

[OCS]

d. Mt 10:26 'For nothing is hidden which will not be revealed' oudèn gár estin kekalumménon hò ouk apokaluphthếsetai ni waiht auk ist gahulip batei ni andhuljaidau zi oč' inč' è i cacowk or oč yaytnesc'i Ničtože bo estŭ pokrŭveno eže ne otŭkrŭveno bodetŭ

e. Mt 7:23 'And then I will profess to them that I have never known you' kaì tóte homologếsō autoîs hóti oudépote égnōn humâs jah pan andhaita im patei ni toanhun kunpa izwis ew yaynžam asac'ic' c'nosa et'e oč' erbek' gitei zjez i togda ispověmı̌ imŭ ěko nikoliže znaxŭ vasŭ

f. Mt 9:33 'Never has such a thing appeared in Israel' oudépote ephánē hoútōs en tōî Israél ni aiw swa uskunp was in Israela ew oč' erbek' erewec'aw ayspisi inč' yIŁI nikoliže avi sę tako vŭ Israeli

g. Mk 9:8 'And immediately looking around, they no longer saw anybody' kaì eksápina periblepsámenoi oukéti oudéna eîdon jah anaks insaibandans ni panaseips ainohun gasehuun Ew yankarcaki hayec'eal aysr andr. oč' ews zok' owrek' tesin i vŭnezaapo vǐžrěvǔše nikogože ne viděšę (Zog: kŭ tomu)

The greatest degree of variation here is seen in Gothic. Most basic is (4a), where Gk. oudeís 'nobody' corresponds to Goth. ni manna, Arm. oč ok', and ocS nikŭtože. Notice here the OCS usage of a genitive object, vina nova, in a negative clause, as well as the double negative, nikŭtože ne, seen in none of the other languages. Other Gothic options for this value include ni mannahun (4b) and ni hashun (4c). The contrast of (4b) and (4c) in OCS (niktože vs. niktože...ne) suggests that the double negative does not appear with the present tense of the verb byti, at least when the latter follows the negation. Another interesting feature of OCS seen here is that this language alone of the four we are investigating possesses no compositional negation or privative prefix but employs its independent negation ne in the phrase ne bélena 'unfulled' as opposed to Gk. agnáphou and Armenian ant'ap'. Gothic here uses a separate lexical item parihs. In the meaning 'nothing' (4d) Gk. oudén corresponds to Goth. ni wait, Arm. oč' inč', and OCS ničtože, again with single negation and present tense of byti. For 'never' Gk. oudépote shows two Gothic correspondences: ni hanhun (4e) and ni aiw (4f). In both instances Arm. has oč' erbek' and ocS nikoliže. Finally, the double negative polarity combination 'no longer anybody' is seen in (4g), where Gk. oukéti oudéna goes with Goth. ni panaseips ainohun, Arm. oč' ews zok' owrek' and 
OCS nikogože ne. Here Armenian shows yet a third negative polarity item, the local owrek' 'anywhere' not found in the other texts, whereas OCS of the Marianus, which again shows a double negative, does not capture the oukéti 'no longer' of Greek. (It is, however, captured by kŭ tomu in the Zographensis.)

\section{[3.2] Negative commands}

The second clause type we shall investigate consists of negative commands. Here Greek shows both $m \bar{e}+$ impv. and $m \bar{e}^{\prime}+$ aor. subj. in simple commands as well as a separate category, often called "Gesetzessprache" in which Greek renders biblical commands from the Hebrew Bible via ou + future. The reason for this is that Biblical Hebrew employs the imperfect tense in these instances, and one usage of the Hebrew imperfect is future, the value which this verbal category assumes in all later stages of the language, including the Rabbinical Hebrew contemporaneous with the Greek NT. Since Hebrew employs its nonmodal negation in these constructions (lo' rather than 'al ), Greek responds with ou rather than mé in these instances. In simple negative commands Gothic employs $n i$ with either the subjunctive or the imperative, Armenian responds with $m i+$ either subjunctive or imperative, and OCS generally shows ne + impv:

(5) a. Mt 6.16 'Don't be like the hypocrites, of sad countenance'

mè gínesthe hốsper hoi hupokritaì skuthrōpoí

ni wairpip swaswe pai liutans gaurai

mi linik' ibrew zkełcaworsn trtmealk'

ne bǫděte ěko i hüpokriti (Zog: sětujošte)

b. Mt 6.13 'And do not lead us into temptation'

kaì mè̀ eisenégkēis hēmâs eis peirasmón

jah ni briggais uns in fraistubnjai

ew mi tanir zmez i p'orjowt'iwn

[GK]

i ne vǐvedi nasŭ vŭ napastř

[GoTH]

[ARM]

[OCS]

c. Mt 10.26 'Therefore do not fear them'

mè̀ oûn phobēthête autoús

ni nunu ogeip izwis ins

$[\mathrm{GK}]$

[GoTH]

[ARM]

[OCS]

Mi aysohetew erknč'ic'ik' i noc'anē

[GK]

[GoTH]

[ARM]

ne uboite sę ubo ixŭ

[OCS]

d. Mt 6.3 'Let your left hand not know what your right hand is doing'

mè gnốtō hē aristerá sou tí poieî hē deksiá sou

ni witi hleidumei peina tua taujip taihswo peina

mi gitasc'ē jax k'o zinč' gorcē aǰ k'o

$[\mathrm{GK}]$

da ne čjuetŭ šjuica tvoě. čito tvoritŭ des'nica tvoě 
e. Mt 5.33 'Do not swear falsely'

ouk epiorkếseis

[GK]

ni ufarswarais

[Goтн]

mi erdnowc'ows sowt

[ARM]

ne vŭ lǔžo klŭneši sę

[OCS]

Examples (5a) and (5b) show, respectively, an imperative and a subjunctive in Greek, and in each instance Armenian and OCS show imperatives. Gothic, however, apes the Greek mood in each case. In (5c), where Greek shows a subjunctive, Armenian shows a subjunctive as well. In this case the Gothic ogeib is a preterite present and therefore shows no opposition between subjunctive and imperative. In (5d) OCS shows da ne + indicative, even though OCS possesses a third person imperative, while Armenian must respond with a subjunctive because it lacks a third person imperative; and again the Gothic preterite present admits only a subjunctive qua imperative. An example of Gesetzessprache is seen in (5e). Here the pres. ind. is to be understood as a future in OCS; but the Armenian subjunctive must be modal because of its negation. In Gothic the present subjunctive is regularly employed in this usage category.

Polarity items within negative commands are seen in (6a)-(6b):

(6) a. Mk 1.44 'See that you say nothing to anybody'

hóra mēdenì mēdèn eípēis

saihv ei mannhun ni qipais waiht

$[\mathrm{GK}]$

zgoyš ler mi owmek' inč' asic'es

$[\mathrm{GoTH}]$

bljudi sę nikomuže ničesože ne ř̌ci

[ARM]

[OCS]

b. Mk 9.25 'I command you: go out from him and no longer enter into him' egố soi epitássō, ékselthe eks autoû kaì mēkéti eisélthēis eis autón [GK] ik pus anabiuda: usgagg us pamma jah panaseips ni galeipais in ina

[GoTH]

es tam k'ez hraman . el i dmanē . ew ayl ews mi mtanic'es i da [ARM] azŭ ti veljo iziti iz nego. i k tomu ne vǐnidi vı̆ nı̆

[OCS]

Example (6a) shows both animate and inanimate polarity in a context where the negative command is treated as a complement clause following an imperative. Gothic alone shows an overt complementizer ei, and Greek, Gothic and Armenian all show subjunctives in the complement clause. Lacking such a category, OCS employs an imperative. Notice again here in OCS the independent negation in addition to that in the polarity items. (6b) shows a "no longer/anymore" type of polarity, and Arm. shows ayl ews mi, lit. 'not further other', while OCS shows $k$ tomu, lit. 'henceforth', not itself a negative polarity item. 


\section{[3.3] Questions}

The next set of negative clause types we shall examine are questions. Greek has two types of non-wh negative question constructions: those expecting a positive reply and those expecting a negative reply. In the first type Greek shows ou or oukhi followed by the indicative, Gothic shows niu (with the Gothic interrogative particle $u)+$ ind., Armenian shows either oč or oč apak'ēn + ind., and OCS shows ne li + ind. (with the OCS interrogative particle li):

(7) Negative questions expecting a positive reply

a. Mt 5.46 'Do not the tax-collectors do the same?' oukhì kaì hoi telônai tò autò poioûsin; niu jah pai piudo pata samo taujand?

oč' apak'ēn ew mak'sawork' znoyn gorcen ne i mytare li tožde tvorętŭ

$[\mathrm{GK}]$ [Gотн] [ARM] [OCS]

b. Mt 7.22 'Have we not prophesied in thy name?' ou tôî sôî onómati proephēteúsamen niu peinamma namin praufetidedum oč' yanown k'o margarēac'ak'? ne vŭ tvoe li imę proročřstvovaxomŭ
[GK]

[Gотн]

[ARM]

[OCS]

In the second question type Gk. mé or méti + ind. corresponds to Goth. ibai + ind., Arm. mit'e or mi et'e + subj., and ocs eda + ind.:

(8) Negative questions expecting a negative reply

a. Mt 9:15 'Can the sons of the bridal canopy weep so long as the bridegroom is with them?' (lit. The sons of the bridal canopy can't weep..., [can they]?)

mè̀ dúnantai hoi huoì toû numphônos pentheîn eph' hóson met' autôn estin ho numphíos;

[GK] ibai magun sunjus brupfadis qainon und pata hweilos pei mip im ist brupfaps?

[GoTH] mi et'e mart' inč' ic'ē mankanc' aragasti sowg ā̄nowl . minč p'esayn and nosa ic'ē

[ARM] eda mogottŭ synove bračŭnii plakati sę. donĭdeže sŭ nimi estŭ ženixŭ

[OCS]

b. Mt 7:16 'Do they collect grape clusters from thorns or figs from thistles?' (lit. They don't collect grape clusters...[do they]?)

mếti sullégousin apò akanthôn staphulàs è apò tribólōn sûka; [GK] ibai lisanda af paurnum weinabasja aippau af wigadeinom smakkans?

[Gотн] 
Mit'e k'ałic'en? i p’šoy xałoł kam i tataskē t'owz

[ARM] eda obemljǫtŭ otŭ trŭniě grozny. li otŭ rěpiě smokŭvi

In the second of these Gothic turns the Greek impersonal into a passive.

A single example of a simple negative wh-question is found in our corpus:

(9) Mk 8:21 'How do you not yet understand?'

pôs oúpō suníete;

haiwa ni nauh frapjip?

isk ziard? oč' imanayk'

kako ne razuměste

This also shows the Greek negative polarity item oúpō 'not yet'. Here all the translations show neg. + ind., but only Gothic is sensitive to the polarity item, rendering it as ni nauh. OCS alone among these passages renders the verb in the past: 'How have you not understood?'

\section{[3.4] Negative purpose clauses}

We now turn to negative purpose clauses. Here Gk. hópōs mmé + subj. and hína mé̀ + subj. correspond to Gothic ei ni + subj., Arm. zi mi + subj., and ocs da ne + ind. Examples are the following:

(10) a. Mt 6.18 'In order that you should not appear to men as fasting' hópōs mè̀ phanēîs toîs anthrốpois nēsteúōn ei ni gasaibuaizau mannam fastands zi mi erewesc'is mardkan ibrew zpahoł da ne aviši sę člověkomŭ postę sę

b. Mk 3.9 'In order that they should not press upon him' hína mè thlíbōsin autón

ei ni praiheina ina

zi mi nełesc'en zna

da ne sŭtǫžajǫtŭ emu

Another type of negative purpose clause may be captured by the English rendition 'lest'. In this category Gk. mépote + subj. corresponds to Goth. ibai haan + subj., Arm. gowc'e or zi mi erbek' + subj., and ocs da ne + ind. or eda kogda + ind.:

a. Mt 5.25 'Lest your adversary give you over to the judge' mếpoté se paradôî ho antídikos tôî kritêî ibai toan atgibai puk sa andastaua stauin 
b. Mk 4.12 'Lest they turn [from their ways] and [their] sins be forgiven them'

mếpote epistrépsōsin kaì aphethêî autoîs tà hamartếmata

[GK] ibai hoan gawandjaina sik jah afletaindau im frawaurhteis

[GoTH] zi mi erbek' darjc'in ew t'ołc'i noc'a eda kogda obratętŭ sę i otŭpustętŭ sę imŭ grěsi

The difference between (11a) and (11b) on the Armenian and ocs level is that both languages are in the second instance sensitive to the polarity value 'ever' (pote) in Gk. mépote (Arm. erbek', OCS kogda). This is captured in both passages by the toan of Gothic. Armenian gowc'e of (11a) is the relexicalized 3rd pers. sg. subjunctive of the verb of existence gol, lit. 'it may be, perhaps'. Gothic ibai, too, may originally have meant 'it may be so' (on which more below).

\section{[3.5] Negative result clauses}

Negative result clauses show Gk. hốste mé + infinitive matched by Goth. swaswe ni + ind., Arm. orpēs zi (o) č ' + ind., and oCs èko ne + ind. Cf. (12a), which also presents the polarity item 'anyone' and a double negation in OCS (ne...niktože). The polarity context 'no longer' is seen in (12b), where Gothic presents the item jupan not yet seen in any passages so far cited. Here the sense of Armenian minč' is something on the order of 'to the point that':

(12) a. Mt 8.28 'So that nobody was able to pass through that way' hốste mè̀ iskhúein tinà pareltheîn dià tês hodoû ekeínēs swaswe ni mahta manna usleipan pairh pana wig jainana orpēs zi č'èr hnar anc'anel owmek' and ayn čanaparh ěko ne možaaše niktože minǫti pǫtemĭ těmı̌

b. Mk 1.45 'So that he was no longer able to enter into the city openly' hốste mēkéti autòn dúnasthai phanerôs eis pólin eiseltheîn swaswe is jupan ni mahta andaugjo in baurg galeipan minč' oč' ews karoł linel nma yaytnapēs i k'ałak' mtanel ěko k tomu ne možaaše ěvě vŭ gradŭ vǐniti

\section{[3.6] Negative conditional clauses}

Negative conditional clauses involve Gk. ei or eàn mé + subj. The simplest case involves a protasis of a negative condition, where Gothic responds with either nibai, niba, or jabai ni + ind., Armenian with et'e oč' or apa t'e oč' + subj., and OCS with ašte ne + ind.: 
(13) a. Mt 5.20 'If your justice be not greater than [that] of the scribes and Pharisees, you will not enter into the kingdom of heaven' eàn mè̀ perisseúsēi humôn hē dikaiosúnē plê̂on tôn grammatéōn kaì Pharisaíōn, ou mè̀ eisélthēte eis tè̀n basileían tôn ouranôn [GK] nibai managizo wairbip izwaraizos garaihteins pau pize bokarje jah Farisaie, ni pau qimip in piudangardjai himine

[GoTH] et'e oč' arawelowc'ow ardarowt'iwn jer aweli k'an zdprac'n ew zP'arisec'woc' oč' mtanic'èk' yark'ayowt'iwn erknic' ašte ne izbǫdetŭ pravda vaša pače knižnikŭ i Farisei. ne imate vŭniti vŭ cěsarǔstvo nebesĭnoje

b. Mk 7.3 'If they do not frequently wash their hands, they don't eat' eàn mè puknà nípsōntai tàs kheîras, ouk esthíousin niba ufta pwahand handuns, ni matjand et'e oč' brinalir lowanan zjerss . hac' oč' owten ašte ne umyjǫtŭ rǫku tŭrǫšte ne ědętŭ

c. Mt 6.15 'If you do not forgive men their sins, neither will your father forgive your sins'

eàn dè mè aphête toîs anthrốpois tà paraptốmata autôn, oudè ho patèr humôn aphếsei tà paraptốmata humôn ip jabai ni afletip mannam missadedins ize, ni pau atta izwar afletip missadedins izwaros

[GoTH] Apa t'e oč' t'ołowc'owk' mardkan zyanc'ans noc'a . ew oč' hayrn jer t'ołc'è jez zyanc'ans jer [ARM] ašte li ne otŭpuštaete člověkomŭ sŭgrěšeni ixŭ. ni oť̌cŭ vašŭ otŭpustitŭ sŭgrěšenii vašixŭ

[OCS]

It seems quite likely that the Gothic subordinators jabai and nibai/niba represent remnants of a thematized present optative of the 'be'-verb $\left(\mathrm{PIE} * b h u \mathrm{H}_{2}\right)$ in the earliest Germanic ${ }^{4}$ with the original values 'and it be', 'it not be', respectively, with perhaps prosodic-based shortening in niba. The third of these passages follows a positive statement of the exact same condition with inverse result, and Gk. dé, Goth. $i p$, and ocs li mark the nexus with the preceding material. In two other passages the negative condition follows a question or a positive universal statement where its value can be captured by English 'except'. In these instances Armenian shows either et'e oč' or bayc' et'e, respectively, 'if not' or 'but if'. In both instances OCS responds with tŭkŭmo 'only, except':

[4] That is, to the same stem (probably *bhw[-e-]) that appears as the base of the Latin future and imperfect in -bit and -bat, respectively. 
a. Mk 2.7 'who can forgive sins except the one God?' tís dúnatai aphiénai hamartías ei mè heîs ho theós; vas mag afletan frawaurhtins niba ains gup? o? karē t'ołowl zmełs , et'e oč' mi AC kto možetŭ otŭpuštati grěxy. tkmo edinŭ bogŭ

b. Mk 6.4 'No prophet is without honor except in his native land' ouk éstin prophêtēe átimos ei mè̀ en tê̄î patrídi autoû nist praufetus unswers niba in gabaurbai seinai oč' è margarē anarg . bayc' et'e i gawar̄i iwrowm něstŭ prorokŭ bečǐsti. tŭkŭmo vŭ svoemĭ otǐčrstvii

In neither of these cases does the negative condition involve a full clause, and this is the reason Greek shows simply ei 'if' rather than eán, which almost always requires a subjunctive.

In two additional instances negative conditionals involving complete clauses are much more complex:

a. Mk 2.21 'otherwise it takes the fullness from it, the new from the old' ei dè mế, aírei tò plếrōma ap' autoû tò kainòn toû palaioû ibai afnimai fullon af pamma sa niuja pamma fairnjin apa t'e oč' ar̄now lrowt'eambn iwrov norn i hnoy anti ašte li že ni vŭzımetŭ konecŭ otŭ neję novoe. otŭ vetŭxaago

b. Mt 6.1 '[Be careful not to perform your almsgiving before men, so as to be seen by them,] otherwise you do not have a reward from your father'

ei dè mége, misthòn ouk ékhete parà tôî patrì humôn

aippau laun ni habaip fram attin izwaramma gowc'ē ew varjs oč' andownic'ik' i hawrē jermē ašte li že ni mŭzdy ne imate. otŭ otǐca vašego

The difficulties in these passages lie in the relationship between their underlying semantic structures and their formal expressions in Greek. In (15a) the preceding clause says 'Nobody sews a patch of unfulled cloth upon an old garment'. The expected continuation of this would be 'for if one does, the new takes the fullness from the old'. However, the first clause may be underlyingly analyzed as possessing two predicates: a higher predicate 'It is not the case that X' and a lower predicate 'somebody sews a patch of unfulled cloth, etc.' The Greek ei dè mé ' and if not' negates the higher predicate, producing a double negative ('If it is not not the case that X') and leaving the lower predicate unaffected. This structure is calqued by both Classical Armenian and OCS (the latter, however, with alternative conjunction li); but Gothic responds in its own idiomatic fashion by assuming the truth of the lower predicate via ibai 'it be so' (originally the affirmative antonym of nibai 'it not be'). 
In (15b) as well there are two predicates: higher 'Be careful to X' and lower 'you do not perform your almsgiving...' Here again Greek negates the higher predicate ('If it is not the case that you are careful'). But in this instance Gothic too denies the higher predicate, not through negation but implicitly through the use of an alternative conjunction 'or' (aippau). ${ }^{5}$ OCS treats this passage just as it does (15a); but the Armenian of (15b) behaves exactly like the Gothic of (15a), assuming the truth of the lower predicate. In fact, the Armenian of (15b) and the Gothic of (15a) constitute an exact match in every regard but etymologically. We have already stated our view that the -bai of Gothic ibai represents an etymological thematic optative to ${ }^{*} b h u H_{2}$, and we may here add that the initial $i-$, a proximal deictic in Indo-European terms, must represent a particle of assertion 'thus, so'. Armenian gowc'e is likewise a subjunctive of a verb of existence, here gol 'be', PIE * ${ }_{2}$ wes 'spend the night, dwell', cf. Gothic wisan 'be'. Its original value is therefore 'it be (so)', just like that of Gothic ibai.

\section{[3.7] Negative causal clauses}

Negative causal clauses are seen in (16a)-(16d):

(16) a. Mk 4.6 'And because it did not have a root, it dried out'

kaì dià tò mè ékhein hrízan eksēránthē

jah unte ni habaida waurtins gapaursnoda

ew zi oč' goyin armatk' . c'amak'ec'aw

[GoTH]

i zane ne iměše koreniě usǔše

b. Mk 8.33 'Get behind me, Satan; for you do not ponder the matters of God'

húpage opísō mou, satanâ, hóti ou phroneîs tà toû theoû

gagg hindar mik, Satana, unte ni frapjis paim gudis

ert' yets im satanay . zi oč' xorhis dow zAYsn

[GK]

idi za mŭnojo Sotono. ěko ne mysliši ě (Zog. ěže) sǫtŭ božěa

[GoTH]

[ARM]

[OCS]

c. Mk 9.6 'for he did not know what he should answer'

ou gàr êédei tí apokrithêi ( $\theta$, etc. elálei 'he was saying'; $A$, D, etc. lalếsei

'he would say'; $\mathrm{W}$, etc. laleî 'he is saying')

[GK]

ni auk wissa ha rodidedi

[Goth]

k'anzi oč' gitēr zinč' xawsēr

[ARM]

ne věděaše bo čto glagoletŭ

[OCS]

d. Mt 9.13 'For I have not come to call the just but sinners'

ou gàr êlthon kalésai dikaíous all' hamartōloús

nip-pan qam lapon uswaurhtans ak frawaurhtans

[5] It should be noted that English 'otherwise', which we have employed to translate both (a) and (b), also denies the higher predicate in each instance. 
zi oč eki koč’el zardars . ayl zmeławors

[ARM]

ne pridŭ bo pravedĭnikŭ prizŭvatŭ. nŭ grěšŭniky

These clauses seem to present a scale of strength from strongly to weakly causal, and all languages but Classical Armenian appear to be sensitive to this distinction. Clearly strongest is the type seen in (16a), where Gk. dià tò mé + inf. corresponds to Goth. unte ni + ind., Arm. zi oč + ind., and OCS zane ne + ind. The Greek, Gothic, and OCS subordinating conjunctions just noted are the strongest causal conjunctions in their respective languages, and this strength is pragmatically indicated as well by the fronting of cause before result. Less strong is the causal value of (16b), where both Gk. hóti ou + ind. and OCS with éko ne + ind. are sensitive to this gradation, but not Gothic and Armenian. Weakest of all is the causal value of Gk. ou gár + ind. seen in (16c) and (16d). The first of these passages, which shows an indirect question as the complement of the verb 'know', is preceded by the episode of the transfiguration of Jesus, after which Peter proposes to make booths for Jesus, Elijah, and Moses. None of the versions follow the text presented by Nestle-Aland, but Gothic and Armenian seem to preserve the reading elálei of $\theta$, etc. and OCS the reading lalései of A, D, etc., less likely lalei of $\mathrm{W}$, etc. The second example follows Jesus' adjuration to the disciples to go and learn the meaning of the biblical statement "I desire mercy and not sacrifice"; and in fact the parallel pericopes in Mark and Luke show no causal conjunction here at all. The weaker causal nexus of these passages is picked up by the Gothic and OCS translators. Gothic shows ni auk + ind. and nip-pan + ind., the second of which is not causal but merely conjunctive. Similarly, OCS captures the Gk. gár by its own fairly weak conjunction bo. Peculiar is Classical Armenian, where $k^{\prime}$ anzi seen in (16c) is in fact the strongest causal conjunction in the language.

\section{[3.8] Negative relative clauses}

Passages involving negative relative clauses are seen in (17a)-(17d):

(17) a. Mt 10.26 'For nothing is hidden which will not be revealed' oudèn gár estin kekalumménon hò ouk apokaluphthếsetai ni waiht auk is gahulip patei ni andhuljaidau zi oč' inč' ē i cacowk or oč' yaytnesc'i

Ničtože bo estŭ pokrŭveno eže ne otŭkrŭveno bodetŭ

[GK] [GoTH] [ARM] [OCS]

b. Mk 4.22 'For there is not anything hidden which will not become clear' ou gár estín ti kruptòn hò eàn mè̀ phanerōthêî nih allis ist ha fulginis patei ni gabairhtjaidau zi č'ē inč' i cacowk . or t'e oč' yaytnesc'i něstŭ bo ničŭtože taino eže ne avitŭ sę
$[\mathrm{GK}]$

[Gотн]

[ARM]

[OCS] 
c. Mk 9.1 'There are some of those standing here who will not taste of death'

eisín tines tôn hôde hestēkótōn hoítines ou mè̀ geúsōntai thanátou

sind sumai pize her standandane pai ize ni kausjand daupaus [Gотн] en omank' i soc'anē or ast kan . ork' mi čašakesc'en zmah sǫtŭ edini otŭ sŭde stojęštiixŭ. iže ne imǫtŭ vŭkusiti sŭmrŭti [OCS]

d. Mk 6.11 'And however many as don't receive you ...'

kaì hósoi àn mè déksōntai humâs ...

jah swa managai swe ni andnimaina izwis ...

Ew or oč' ənkalc'in zjez ...

These passages show some subtleties in Greek depending on the degree of indefiniteness of the relative clause; and these are often not reflected in the translations. Thus, (17a) and (17b) differ in Greek in the fact that the first shows relative pronoun $+o u+$ fut. and the second relative pronoun + eàn mé + subj. Presumably, the latter is to be understood as less definite than the former, an inference that is echoed also by a detail: in the first passage Greek shows the orthotonic oudén 'nothing' in the opening clause, while in the second it has the enclitic $t i$ in the first clause. A hypothesis that immediately presents itself is that the enclitic signals a more indefinite value than the orthotonic. But Gothic alone of the translation languages is sensitive to this, opposing indefinite pronominal to to nominal waiht. OCS here shows an interesting variation between (17a) and (17b) which may turn out to be significant: in (17a) ničtože precedes the copula without an independent negation, as seen earlier; but in (17b) ničŭtože follows the present tense of byti in existential value, and an independent negation is soddered onto the verb in the form něstŭ. The difference appears to be like that of English 'nothing is' but 'there is not anything'. But (4c) cited earlier had niktože bo estŭ in the value 'there is nobody', so we may be dealing with a syntactic feature related solely to the position of estŭ relative to the negative universal. Note that Gk. eàn in (17b) is not the same item as the conditional particle seen in (13), but is a substitute for án, as frequently in the NT. The Armenian translator alone feels obliged to capture this with t'e, a less frequent variant of its own conditional particle et'e. Related to these passages is (17c), which shows the typical Greek apparatus for signaling future negation (ou $m \bar{e}+$ subj.), here within a "qualifying" relative clause introduced by hoitines and following an indefinite clause. This clause in Greek is equivalent to a prediction and as such is matched by the Gothic present indicative qua future and OCS periphrastic future involving imati + infinitive. But Armenian with its modal negation treats this as falling short of a definite outcome. Here the Gothic pai ize (=izei) seems to be a calque on Gk. hoitines. Finally, (17d) shows the indefinite Greek relative hósoi àn m ${ }^{\prime} \bar{e}+$ subj. The value of hósoi is cap- 
tured in Gothic by swa managai swe and in OCS by eliko ašte + ind. Armenian, on the other hand, shows a simple headless relative or in indefinite value.

We include in this category several passages in which Greek shows mée at least two of the translational versions show relative clauses:

a. Mt 7.19 'Every tree not producing good fruit is cut down' pân déndron mè̀ poioûn karpòn kalòn ekkóptetai all bagme ni taujandane akran god usmaitada Amenayn car̄ or oč' ā̄nē ptowł bari hatani visěko drěvo eže ne tvoritŭ ploda dobra. posěkajǫtŭ

b. Mt 7.21 'Not everyone saying to me, "Lord, Lord" will enter the kingdom of heaven' ou pâs ho légōn moi . kúrie, kúrie, eiseleúsetai eis tè̀n basileían tôn ouranôn ni hazuh saei qipip mis: frauja, frauja! inngaleipip in piudangardja himine Oč' amenayn or asē c'is TR TR mtc'ē yark'ayowt'iwn erknic' [ARM] Ne vı̌sěkŭ glagolęi mǐně. gospodi gospodi vĭnidetŭ vŭ cěsarǐstvie nebeš̌skoe

These passages show an interesting scope variation in the universal quantifier 'every/everyone'. In (18a) Gk. pân has broad scope over the negation, and this is matched in the translation languages, of which Armenian and OCS show relative clauses. In (18b) Gk. pâs functions within the negation, and here, too, the translations place their universal quantifier after the negation. This results in a change in the form of negation in Greek and a change in the quantifier in Gothic.

\section{[3.9] Sequential negation}

We turn now to instances of sequential negation. A wide range of structures is represented, and these can be broken down into nominal, phrasal, and clausal types. Strictly nominal conjoined sequences are seen in (19a) and (19b):

(19) a. Mt 6.20 'where neither moth nor corrosion [lit. consumption] ruins' hópou oúte sè̀s oúte brôsis aphanízei parei nih malo nih nidwa frawardeip owr oč' c'ec' ew oč' owtič apakanen [GoTH] ideže ni črŭvı̌ ni tilě tilitŭ

b. Mt 9.13 'I desire mercy and not sacrifice' éleon thélō kaì ou thusían armahairtipa wiljau jah ni hunsl zołormowt'iwn kamim ew oč' zzoh milostyni xoštǫ a ne žrŭtvě 
In the first of these the archaic Greek sequence oúte $\mathrm{N}_{1}$ oute $\mathrm{N}_{2}$ is matched by Goth. nih $\mathrm{N}_{1}$ nih $\mathrm{N}_{2}$, Arm. oč $\mathrm{N}_{1}$ ew oč ' $\mathrm{N}_{2}$, and OCS ni $\mathrm{N}_{1}$ ni $\mathrm{N}_{2}$. The Gothic sequence represents PIE *ne $k^{w} e$, with the same enclitic conjunction reflected in Greek te. Classical Armenian has lost this old conjunction and therefore shows its only conjoined negation structure oč...ew oč. OCS shows its serial negation ni, ultimately ne + conjunction $i$, which we have seen in a number of passages already cited. This passage shows pure serial conjunction. The same is not true of (19b), which is implicitly oppositional with its positive/negative component. Here Greek shows the sequence $\mathrm{N}_{1}$ kai ou $\mathrm{N}_{2}$ with orthotonic, static (i.e. non-serial) conjunction; and this is matched by the equivalent orthotonic dyad $\mathrm{N}_{1}$ jah $n i \mathrm{~N}_{2}$ in Gothic and the invariant sequential ew oč' in Armenian. OCS, on the other hand, captures the implicit nuance of this structure with the oppositional rather than serial a ne.

Phrasal conjunction involving four conjoined prepositional phrases following a negative infinitival clause is seen in (20), where Gk. méte is iterated across every conjoined member, but Gothic shows the enclitic conjunction only in members 2-4. Similar in format is Armenian, whereas OCS shows four iterations of ni:

(20) Mt 5.34-36 'But I say to you not to swear at all: neither by heaven...nor by earth...nor by Jerusalem; nor should you swear by your head' egò̀ dè légō humîn mè omósai hólōs, mête en tōî ouranôî...mête en têî gệ̂... mête eis Hierosóluma...méte en têî kephalêî sou omósēis appan ik qipa izwis ni swaran allis, ni bi himina...nih bi airpai...nih bi Iairusaulwmai...nih bi haubida peinamma swarais

[GoTH] Aył es asem jez . amenewin mi erdnowl . mi yerkins... Ew mi yerkir...ew mi yĒM...ew mi i glowx k'o erdnowc'ows [ARM] azŭ že glagoljo vamŭ. ne klęti sę otŭnǫdŭ ni nebesemŭ...ni zemlejǫ...ni Ierusalemŭmŭ...ni glavojo svoejo klŭni sę [OCS]

Word-level conjunction involving verbs is seen in (21a)-(21b):
a. Mt 6.20 'where thieves do not dig through and steal' hópou kléptai ou diorússousin oudè kléptousin parei piubos ni ufgraband nih stiland ew oč' gołk' akan hatanen ew gołanan ideže tatie ne podŭkopavajǫtŭ. ni kradǫtŭ
b. Mt 6.28 'they do not toil nor spin' ou kopiâî oudè nếthei nih arbaidjand nih spinnand oč ǰanay ew oč' niwt'ē ne truždajotŭ sę ni prędǫtŭ 
In the first of these passages Greek shows the structure ou...oudé with the quasienclitic dé which is a vibrantly living conjunction in the NT, whereas te is largely moribund in this text. Gothic responds exactly with its ni...nih, and OCS equivalently with ne...ni. The Armenian rendition is independent with its single negation. This passage is a continuation of (19a) and suggests that perhaps on its way to obsolescence $\mathrm{Gk}$. te was first reduced to nominal conjunctive value. We cite (21b) because of its contrast with (21a) on the Gothic level, showing that the Goths had their own intuitions about where serial negation was appropriate (nih...nih : ou...oudé [b] vs. ni...nih : ou...oudé [a]).

A more complex sequence is the following:

(22) Mk 8.18 'Having eyes, do you not see and having ears, do you not hear? And you do not remember...

ophthalmoùs ékhontes ou blépete kaì ôta ékhontes ouk akoúete; kaì ou mnēmoneúete...

[GK] augona habandans ni gasaihvip, jah ausona habandans ni gahauseip jah ni gamunup...

[Gотн] ač'k' gon ew oč'? tesanēk' . akanǰk' en ew oč' lsēk' . ew oč' imanayk' takawin ew oč' yišēk'...

[ARM]

oči imǫšte ne vidite. i uši imǫšte ne slyšite. i ne pomĭnite li...

[OCS]

In this passage Greek shows the structure $\mathrm{O}_{1} \mathrm{ppl}_{1}$ ou $\mathrm{V}_{1}$ kai $\mathrm{O}_{2} \mathrm{ppl}_{1}$ ou $\mathrm{V}_{2}$ kai ou $V_{3}$. Gothic exactly follows the Greek here, as does OCS, which therefore does not treat the verbs as serial but rather as three completely independent clauses, hence ne rather than ni. OCS also understands the last part of the structure as a question (note the particle li). Armenian shows multiple variations from the other versions, including the rendition of both participles by finite verbs, the addition of the verb imanal 'understand', and the introduction of the negative polarity item takawin 'yet'. ${ }^{6}$

We complete our discussion of sequential negation by citing three passages in which the negation is not straightforwardly sequential, but rather adverbial:

[6] The final part of this structure is confusing when presented in isolation from its following verse. The King James Version does indeed treat the last clause as a question. But in Greek it is possible to take the question as continuing into the next verse, in which case the wh-word pósous 'how many?' would have to be understood as posing an indirect question: 'And do you not remember, when I broke the five [pieces of] bread into five thousand, how many baskets full of fragments you picked up?' Nestle-Aland's text punctuates the Greek in precisely this way, as does Streitberg's Gothic text, at least for the stretch 'when I broke...you picked up?' [Streitberg treats jah ni gamunup as part of the prior sentence and hence as standing outside the question]. But both the Armenian and OCS texts show a full stop after 'five thousand', continuing with a conjunction 'and' followed by a direct wh-word (kani?, koliko). The Armenian text is in any event deficient in not translating Greek éklasa 'I broke'. Consequently, the OCS best captures the pragmatic value of the phrase 'And do you not remember', while going its own way in assessing the relationship between this clause and the indirect question which follows. 
(23) a. Mk 5.3 'who had his dwelling in the tombs, and nobody was able to bind him even with chains'

hòs tè̀n katoíkēsin eîkhen en toîs mnếmasin, kaì oudè halúsesin oudeìs edúnato autòn dêsai

[GK]

saei bauain habaida in aurahjom: jah ni naudibandjom eisarneinaim manna mahta ina gabindan

[Gотн]

oro ew bnakowt'iwn iwr isk i gerezmans ēr. ew oč' šłt'ayiwk' ok' ews karēr kapel zna

[ARM]

iže žilište iměaše vŭ groběxŭ. i ni želěznomŭ qžemĭ ego niktože ne možaaše sŭvęzati

[OCS]

b. Mk 2.2 'And straightway many gathered, so that there was no longer any room, even by the door'

kaì euthéōs sunếkhthēsan polloí, hốste mēkéti khōreîn mēdè tà pròs tè̀n thúran

[GK]

jah suns gaqemun managai, swaswe jupan ni gamostedun nih at daura

[GoTH] ew žołovec'an bazowmk' . minč'ew tełi ews oč' linel ew oč' ar̆ drann [ARM] i abǐe sŭbŭrašę sę mŭnodzi. ěko kŭ tomu ne vĭměštaaxo sę ni prědŭ dverı̆mi

[OCS]

c. Mt 6.15 'If you do not forgive men their sins, neither will your father forgive your sins'

eàn dè mè aphête toîs anthrốpois tà paraptốmata autôn, oudè ho patèr humôn aphếsei tà paraptốmata humôn

[GK] ip jabai ni afletip mannam missadedins ize, ni pau atta izwar afletip missadedins izwaros

[GoTH]

Apa t'e oč' t'ołowc'owk' mardkan zyanc'ans noc'a . ew oč' hayrn jer t'ołc'ē jez zyanc'ans jer

[ARM]

ašte li ne otŭpuštaete člověkomŭ sŭgrěšeni ixŭ. ni otǐcŭ vašŭ otŭpustitŭ sŭgrěšenii vašixŭ

[OCS]

In (23a) the second conjunct in Greek shows kaì oudè...oudeís, where oudè is to be understood as adverbial '(not) even'. Hence, the Greek shows a double negation from an English perspective. In OCS this value is captured translationally by $n i$, while niktože ne mogaaše shows the usual double negation we have learned to expect in these cases. Gothic shows jah ni...mann, ignoring the Greek oudè, and Armenian, instead of repeating ew, the usual way of saying 'even' in this language, employs ews, as if to say 'and nobody was able anymore'. In (23b) and (23c) one finds adverbial negation following a result clause which in the first instance contains negative polarity mēkéti 'no longer'. Here Gk. mèdè tà pròs tè̀n thúran is translated in Gothic as nih at daura, in Armenian as ew oč' ar drann, and in OCS as ni prědŭ dverĭmi, all of which 
say 'not even at the door'. Finally, in (23c) the two clauses are not coordinated but rather the first is the protasis of a negative condition and the second is the apodosis. Gk. oudé can be understood as meaning 'neither' here; and to this Gothic rather reacts with $n i$ + the apodotic particle pau signaling resultative 'then' and Armenian with the calque ew oč , here probably to be understood adverbially as 'also not', as is OCS ni.

\section{[3.10] Minor categories}

There remain only three sparsely attested negative categories that we shall now address. The first of these is the bare negative used in a reply (24). Here Gothic alone shows a special negation ne, while OCS employs its serial negator ni. Armenian in this passage shows a special use of its postposed definite article $-n$ in quotative value:

$$
\begin{aligned}
& \text { Mt } 5.37 \text { 'Let your word be "aye, aye; nay, nay". } \\
& \text { éstō dè ho lógos humôn naí naí, oú oú } \\
& \text { sijaip-pan waurd izwar: ja, ja; ne, ne } \\
& \text { Aył ełic'i jer ban . ayon . ayo . ew oč’n . oč' } \\
& \text { bǫdi že slovo vaše ei ei. i ni ni }
\end{aligned}
$$

$[\mathrm{GK}]$

[Gотн]

[ARM]

[OCS]

Finally, it is well known that both complements of comparatives and clauses of prior circumstance are negative polarity contexts. Cf. English John is smarter than anybody (else) I know or The police apprehended the suspect before he could harm anybody with negative polarity anybody rather than positive somebody. Similarly, with actual negation, French Il est plus riche qu'on ne pense or Il existait un monde où l'artiste trouve avant qu'il ne cherche (J. Cocteau). Of the languages in our study, OCS alone shows an overt polarity negation in these contexts, either freestanding or in univerbation with a following morpheme (25a)-(25b). Cf. the use of nor for than in some English dialects (He is taller nor I am):

(25) a. Mk 9.45 'It is better for you to enter into life lame than having two feet, to be cast into Gehenna'

kalón estín se eiseltheîn eis tè̀n zōèn khōlón, è toùs dúo pódas ékhonta blēthênai eis tèn géennan dobrěa (Zog.: -ěe) ti estŭ vŭniti vŭ životŭ xromu. neže dvě nodzě imǫšte (Zog.: imoštju). vŭvrǔženu byti vŭ heono

[OCS]

b. Mt 1.18 'Before the two had come together, she was found to be pregnant by the holy spirit'

prìn è suneltheîn autoùs heuréthē en gastrì ékhousa ek pneúmatos hagíou

prěžde daže ne sŭnidosta sę obrěte sę imǫštii vŭ črěvě bě otŭ duxa svęta

[OCS] 


\section{[4] CONCLUSIONS}

In conclusion, I must emphasize that although the material presented in this article is comprehensive for the parts of the text it has covered, some $80 \%$ of the text has yet to be canvassed. This will no doubt yield some additional categories and perhaps some new relationships among the means employed to express negation in the various languages of our survey. However, it is unlikely to change greatly the picture presented here, which is remarkable for its consistency from language to language. Once the total range of data concerning negation and polarity in the entire extant text of the Gospels in all four languages has been gathered, analyzed, and presented, an important chapter in the comparative grammars of these languages will have been achieved.

\section{REFERENCES}

Bucsko, John M. 2008. Preverbs and idiomatization in Gothic: University of Georgia dissertation.

Condon, Nancy L. 1990. A distributional and discourse analysis of - $(u) h$ and other conjunctions in the Gothic Bible. University of Georgia MA thesis.

Cowgill, Warren. 1960. Greek ou and Armenian oč. Language 36. 347-50.

Cuendet, Georges. 1924. L'impératif dans le texte grec et dans les versions gotique, arménienne et vieux slave des Evangiles. Paris: Librairie Orientaliste Paul Geuthner.

Cuendet, Georges. 1929. L'ordre des mots dans le texte grec et dans les versions gotique, arménienne et vieux slave des Évangiles. Première partie. Les groupes nominaux. Paris: Champion.

Fauconnier, Gilles. 1975. Polarity and the scale principle. PCLS 11. 188-99.

Govberg-Afros, Elena. 2002. Aspects of old Germanic hypotaxis: the relative clause in focus: Hebrew University of Jerusalem dissertation.

Horn, Laurence R. 1989. A natural history of negation. Chicago-London: The University of Chicago Press.

Jagič, V. (ed.). 1954. Quattuor evangeliorum codex glagoliticus, olim Zographensis nunc Petropolitanus. Characteribus cyrillicis transcriptum notis criticis prolegomenis appendicibus auctum. Graz: Akademische Druck- u. Verlagsanstalt.

Jagič, V. (ed.). 1960. Quattuor evangeliorum versionis palaeoslavenicae codex Marianus glagoliticus. Characteribus cyrillicis transcriptum. Graz: Akademische Druck- u. Verlagsanstalt. 
Kim, Taejin. 1992. The particle pa in the West-Saxon Gospels: A discourse-level analysis: University of Georgia dissertation.

Klein, J. S. 1992a. On the independence of Gothic syntax, I: Interrogativity, complex sentence types, tense, mood, and diathesis. Journal of Indo-European Studies 20. 339-79.

Klein, J. S. 1992b. On the idiomatic nature of the Gothic New Testament: A comparative study of prepositional usage in Gothic and New Testament Greek. Transactions of the Philological Society 90. 1-80.

Klein, J. S. 1994. Gothic paruh, panuh, and -(u)h pan. Indogermanische Forschungen 99. 253-76.

Klein, J. S. 1996. On personal deixis in Classical Armenian. A study of the syntax and semantics of the n-, s-, and d-demonstratives in manuscripts $E$ and $M$ of the Old Armenian Gospels. Dettelbach: J. H. Röll.

Klein, J. S. 1997. Indefinite pronouns, polarity, and related phenomena in Classical Armenian: A study based on the Old Armenian Gospels. Transactions of the Philological Society 95. 189-245.

Klein, J. S. \& Nancy L. Condon. 1993. Gothic -(u)h: A synchronic and comparative study. Transactions of the Philological Society 91. 1-62.

Künzle, Beda (ed.). 1984. Das altarmenische Evangelium/L'Evangile arménien ancien. Teil I/Ière partie: Edition. Bern-Frankfurt am Main-New York: Peter Lang.

Ladusaw, William A. 1980. Polarity sensitivity as inherent scope relations. New YorkLondon: Garland Publishing, Inc.

Martin, Chris. 2004. The syntax of the verb in Old English relative clauses: An analysis of the Anglo-Saxon Gospels: University of Georgia dissertation.

Nestle, Erwin \& Kurt Aland (eds.). 1979. Novum Testamentum graece. 26. neu bearbeitete Auflage. Stuttgart: Deutsche Bibelgesellschaft.

Pennington, Joseph A. 2010. A study of purpose, result, and causal hypotaxis in early Indo-European Gospel versions: University of Georgia dissertation.

Streitberg, W. (ed.). 1971. Die gotische Bibel. Heidelberg: Carl Winter.

Thomason, Olga A. 2006. Prepositional systems in Biblical Greek, Gothic, Classical Armenian, and Old Church Slavic: University of Georgia dissertation.

Tunkle, Eph Herbert. 2000. Gothic forefield syntax: Focus, repair, and Wackernagel's law: University of Georgia dissertation. 
Zwarts, Frans. 1995. Nonveridical contexts. Linguistic Analysis 25. 286-312.

AUTHOR CONTACT INFORMATION

Jared S. Klein

Department of Classics

Park Hall

The University of Georgia

Athens, GA 30602

U.S.A.

jklein@uga.edu 